\title{
Extraction and Chemical Characterization of Humic Acid from Nitric Acid Treated Lignite and Bituminous Coal Samples
}

\author{
Noureen Fatima ${ }^{1}$, Asif Jamal ${ }^{1}$, Zaixing Huang ${ }^{2}$, Rabia Liaquat ${ }^{3}$, Bashir Ahmad ${ }^{4}$, Rizwan Haider ${ }^{5}$, \\ Muhammad Ishtiaq Ali ${ }^{1, *}$, Tayyba Shoukat ${ }^{6}$, Zeid A. ALOthman ${ }^{7}{ }^{\circ}$, Mohamed Ouladsmane ${ }^{7}$, , Tariq Ali $^{8}$, \\ Shafqat Ali ${ }^{9,10, * \mathbb{D}}$, Naseem Akhtar ${ }^{11}$ and Mika Sillanpää ${ }^{12, *(\mathbb{D}}$
}

1 Department of Microbiology, Quaid-i-Azam University Islamabad, Islamabad 45320, Pakistan; neenofatima26@gmail.com (N.F.); asifjamal@qau.edu.pk (A.J.)

2 School of Chemical Engineering and Technology, University of Mining and Technology, Xuzhou 221116, China; zhuang@uwyo.edu

3 U.S. Pakistan Centre for Advanced Studies in Energy, National University of Sciences and Technology, Islamabad 45320, Pakistan; rabia@casen.nust.edu.pk

4 Department of Biological Sciences, International Islamic University, Islamabad 44000, Pakistan; bashir.ahmad@iiu.edu.pk

5 Institute of Energy \& Environmental Engineering, University of Punjab, Lahore 54590, Pakistan; rizwan.ieee@pu.edu.pk

check for updates

Citation: Fatima, N.; Jamal, A.; Huang, Z.; Liaquat, R.; Ahmad, B.; Haider, R.; Ali, M.I.; Shoukat, T.; ALOthman, Z.A.; Ouladsmane, M.; et al. Extraction and Chemical Characterization of Humic Acid from Nitric Acid Treated Lignite and Bituminous Coal Samples. Sustainability 2021, 13, 8969 https://doi.org/10.3390/ su13168969

Academic Editors: Shahid Hussain, Awais Ahmad and Shagufta Kamal

Received: 19 June 2021

Accepted: 23 July 2021

Published: 11 August 2021

Publisher's Note: MDPI stays neutral with regard to jurisdictional claims in published maps and institutional affiliations.

Copyright: () 2021 by the authors. Licensee MDPI, Basel, Switzerland. This article is an open access article distributed under the terms and conditions of the Creative Commons Attribution (CC BY) license (https:// creativecommons.org/licenses/by/ $4.0 /)$.
6 Department of Chemistry, Government College University, Faisalabad 38000, Pakistan; tayybashoukat97@gmail.com

7 Chemistry Department, College of Science, King Saud University, Riyadh 11451, Saudi Arabia; zaothman@ksu.edu.sa (Z.A.A.); mouladsmane@ksu.edu.sa (M.O.)

8 Department of Chemistry, The University of Lahore, Lahore 54590, Pakistan; verpoortfrancis@gmail.com

9 Department of Environmental Science and Engineering, Government College University, Faisalabad 38000, Pakistan

10 Department of Biological Sciences and Technology, China Medical University, Taichung 40402, Taiwan

11 Department of Chemistry, The Government Sadiq College Women University, Bahawalpur 63100, Pakistan; doctorujs@gmail.com

12 Department of Civil and Environmental Engineering, Florida International University, Miami, FL 33199, USA

* Correspondence: ishi_ali@hotmail.com (M.I.A.); shafaqataligill@yahoo.com (S.A.); mikaesillanpaa@gmail.com (M.S.)

Abstract: Currently, conversion of coal into alternative fuel and non-fuel valuable products is in demand and growing interest. In the present study, humic acid was extracted from two different ranks of coal, i.e., low rank and high rank (lignite and bituminous), through chemical pretreatment by nitric acid. Samples of lignite and bituminous coal were subjected to nitric acid oxidation followed by extraction using $\mathrm{KOH}$ and $\mathrm{NaOH}$ gravimetric techniques. The chemical pretreatment of both types of coal led to enhanced yields of humic acid from $21.15 \%$ to $57.8 \%$ for lignite low-rank coal and $11.6 \%$ to $49.6 \%$ bituminous high rank coal. The derived humic acid from native coal and nitric acid treated coal was analyzed using elemental analysis, E4/E6 ratio of absorbance at $465 \mathrm{~nm}$ and $665 \mathrm{~nm}$ using UV-Visible spectrophotometry and Fourier transformed infrared spectroscopy FTIR. The chemical characteristics of coal treated with nitric acid have shown increased molecular weight and improved aromaticity with more oxygen and nitrogen and lower $\mathrm{C}, \mathrm{H}$, and sulphur content. The E4/E6 ratio of nitric acid-treated low and high ranks of coal was high. The FTIR spectroscopic data of nitric acid-treated lignite coal indicates an intensive peak of carboxyl group at $2981.84 \mathrm{~cm}^{-1}$, while bituminous coal was shown in cooperation with the $\mathrm{N}-\mathrm{H}$ group at $2923.04 \mathrm{~cm}^{-1}$. SEM was performed to detect the morphological changes that happen after producing humic acid from $\mathrm{HNO}_{3}$ treatment and native coal. The humic acid produced from $\mathrm{HNO}_{3}$ treated coal had shown clear morphological changes and some deformations on the surface. SEM-EDS detected the major elements, such as nitrogen, in treated humic acid that were absent in raw coal humic acid. Hence, the produced humic acid through $\mathrm{HNO}_{3}$ oxidation showed a more significant number of humic materials with improved efficiency as compared to native coal. This obtained humic acid can be made bioactive for agriculture purposes, i.e., for soil enrichment and improvement in growth conditions of plants and development of green energy solutions. 
Keywords: lignite coal; bituminous coal; pretreatment; nitric acid

\section{Introduction}

Chemically, coal is considered to be a complex structure, and conversion of coal into useful simpler substances of low molecular weight is considered to be a convenient and most appropriate method, compared to conventional utilization of coal [1]. Few of these low molecular weight fractions may be value-added chemical entities. These fractions from low rank lignite coal can be separated by strong alkali treatment and that mainly results in the isolation of three components (alkali-soluble and acid-insoluble, alkali-insoluble, and acid-soluble) [1,2]. The acid-insoluble and alkali-soluble fraction from lignite coal is called humic acid and contains about $20-80 \%$ of the organic content in lignite [3].

Humic acid is also known as polyhydroxy carboxylates that include aliphatic and aromatic subunits [4]. It is light brown to the black, heterogeneous, and multifaceted organic polymer that is created through secondary synthesis reactions [5]. Humic acid is proactive and interacts with organic and inorganic chemicals when compared with other substances. Some amine and aromatic groups are found to be present in humic acids that are active biologically in the growth of plants. The other groups that include phenols [5,6], carboxylates, hydroxyl, and ketones [7] help to expand the ion exchange capability of soils [8].

Currently, low rank coal that mainly includes peat and leonardite is not used commercially because they have less energy content but, on the other hand, these are considered rich sources of humic fractions [9]. Likewise, high rank bituminous coal is relatively soft and contains a tar-like substance known as bitumen. Principally, the insolubility of high rank coal can be made soluble through oxidation which introduces and increases the acidic groups in coal molecules [10].

Pakistan contains about 185 billion tons of coal reservoirs from all of its provinces. The major coal reserves exist in Thar, Lakhra (Sindh) Loralai, Duki, Chamalang (Balochistan), Mianwali, Makarwal, Khushab (Punjab), Narran, and Kotli (KPK) [11]. The category of Pakistani coal falls into different coal ranks and types that include lignite, sub-bituminous, and bituminous, but the low rank lignite shares the largest reservoirs of the country [11,12].

The structure of humic acid contains a mixture of small, large, and polydisperse moieties that are formed through the process of transformation and decomposition of microbial strains. The geochemical reaction also plays an important role in the formation of humic acids and humates [13]. One of the structures proposed by [14] says that humic acid is formed by the alkyl benzene moieties that are attached through covalent bonds. While another author, Piccolo [15], proposed that humic acid is a structure that is made up of small heterogeneous molecules that are bound together by hydrogen bonds and hydrophobic dispersive forces. Various other authors suggested that the structure of humic acid depended upon the sources that generated it and specific conditions of extraction as well. Humic acid carries several applications in various fields, i.e., medicine, agriculture, wastewater treatment, health, and many other applications. Humic acid can improve the quality of water and remove metal ions efficiently. It can also be used as ceramic additives, water-soluble fertilizer, soil remediation, flocculant, surfactant, and a battery cathode expansion agent [16]. It is also a good absorbent with the ability to treat pollution created by gases produced through waste substances [4-17]. Humic acid is found to be present in marsh soils, lakes, lignite, peat, bituminous coal, shale, weathered coal, flora and fauna residues, and shale areas.

The lignite type of coal carries significant attention as its reserves are present $45 \%$ globally $[17,18]$. But on the other hand, it has a wide number of oxygen functional moieties, high moisture content, and a low calorific value which has confined its wide and direct use. The humic acid extracted from the lignite type of coal has a high content of carbon, lower oxygen and nitrogen, very few carboxylic groups, and more aromatic groups. It also has 
cross-linking of ethylene and methylene between aromatic moieties [19]. As compared to humic acid from soil and peat, lignite humic acid contains long chains of saturated alkanoic acids $[19,20]$. However, the humic acid produced from bituminous and mature coal under mild oxidation produces humic substances and humins and it is observed that few soluble non-alkali materials are present in bituminous coals [21].

Humic acid under an acidic environment is insoluble but, under alkaline and basic conditions, it becomes soluble. Various methods have been proposed for the extraction of humic acid from lignite, including physical, biological, and chemical methods [22]. The present study aims at the extraction of humic acid from indigenous lignite and bituminous coal, categorized as low and high rank, by using the alkali-acid method and characterization of precipitated humic acid by UV-VIS, FTIR, elemental analysis, and SEM-EDS. Furthermore, this study will be focused on the economic value and application of humic acid extracted from coal.

\section{Materials and Methods}

\subsection{Reagents and Chemicals}

All the solvents and reagents used in the study were of analytical grade and obtained from Sigma Aldrich and were used without purification. The solutions were prepared by using deionized water. The samples of lignite coal were collected from the Thar coal mine in Sindh and bituminous coal was collected from the Duki coal mine, Baluchistan, Pakistan. All the samples were collected in sterilized bags and stored in a dry place.

\subsection{Coal Samples Preparation}

Coal samples from the Thar and Duki coal mines, weighing almost $20-30 \mathrm{~kg}$, were collected and transported to the Environmental Microbiology lab, Quaid-I-Azam University, Islamabad, Pakistan. For carrying out the experimental study, about $2 \mathrm{~kg}$ of each sample was selected by using the quarter and conning method. The samples were crushed into fine particles using mortar and pestle. Later on, the coal samples were sieved through 60 mesh $(0.25 \mathrm{~mm})$ and were stored in a sterilized plastic bag having a quantity of about $1 \mathrm{~kg}$. For carrying out proximate analysis, the coal sample was investigated using the standard ASTM method.

\subsection{Acidic Pretreatment of Coal Using Nitric Acid $\left(\mathrm{HNO}_{3}\right)$}

For pretreatment of coal samples, the working solution of $\mathrm{HNO}_{3}$ was prepared freshly. To prepare about $2 \%$ working solution of $\mathrm{HNO}_{3}, 65 \%$ of concentrated $\mathrm{HNO}_{3}$ (laboratory Grade) was used. About $50 \mathrm{~g}$ of each coal sample was allowed to oxidize using $100 \mathrm{~mL}$ of $2 \% \mathrm{HNO}_{3}$ freshly prepared in a beaker and allowed to stir gently for $1 \mathrm{~h}$ and were placed for $24-48 \mathrm{~h}$ at $30^{\circ} \mathrm{C}$. The coal content was then filtered and washed again and again with distilled and deionized water at $8000 \mathrm{rpm}$ for $5 \mathrm{~min}$ so that unreacted acid was washed out properly. The treated coal sample was dried in an oven at $40{ }^{\circ} \mathrm{C}$ for $2-3 \mathrm{~h}$. The treated and washed coal content was kept safe in sealed plastic bags to further use it for extraction studies of humic acid.

\subsection{Extraction of Humic Acid by $\mathrm{KOH}$}

The pretreated lignite and bituminous coal were allowed to mix with $0.5 \%, 1.5 \%, 2.5 \%$, $3.5 \%$, and $4.5 \% \mathrm{KOH}$ solutions, and experiments were carried out for $24 \mathrm{~h}$ with continuous stirring. Later on, reaction content was filtered. The filtrate of each coal sample with different $\mathrm{KOH}$ concentrations was kept in sealed bottles for further experimental study.

\subsection{Extraction of Humic Acid Using $\mathrm{NaOH}$}

The method for extracting humic acid using $\mathrm{NaOH}$ was modified from [18]. The alkaline extraction of humic acid using $\mathrm{NaOH}$ is suitable at an industrial level as alkali is safe to use and is non-toxic. It results in the production of humic fertilizers that help to improve soil aeration, aggregation, and increase water holding capacity. First, $1 \mathrm{~g}$ of 
each lignite and bituminous coal was mixed with $100 \mathrm{~mL}, 0.1 \mathrm{M} \mathrm{NaOH}$ with continuous stirring at $20^{\circ} \mathrm{C}$ for $24 \mathrm{~h}$. The coal suspension was then centrifuged at $8000 \mathrm{rpm}$ for $10 \mathrm{~min}$ and the supernatant was separated using Whatman no. 1 filter. The $\mathrm{pH}$ of the supernatant was adjusted to 1.8 by using $6 \mathrm{M} \mathrm{HCL}$. The supernatant was then left for precipitation for $24 \mathrm{~h}$. After $24 \mathrm{~h}$, the precipitate was collected by centrifugation at $8000 \mathrm{rpm}$ for $15 \mathrm{~min}$. The precipitated humic acid was washed with Milli $Q$ water for about 3 to 4 times and dried at $40{ }^{\circ} \mathrm{C}$ in an oven and stored for further experimental study at $4{ }^{\circ} \mathrm{C}$.

\section{Analysis}

\subsection{Humic Acid Determination Using Spectrophotometry}

The UV visible spectrophotometry was used to determine the absorption ratios with SPECORD 200 Analytic UV-Vis spectrophotometer (Jena, Germany). The humic content was allowed to dissolve in $0.05 \mathrm{M} \mathrm{NaHXO}_{3}$ solution ( $\mathrm{pH} 8.4$ ) with humic acid concentration $40 \mathrm{mg}$ per liter. The solution was centrifuged at $7000 \mathrm{rpm}$ at room temperature for $5 \mathrm{~min}$. The sodium bicarbonate buffer was run as a blank and the absorbance spectrum was taken at wavelength $465 \mathrm{~nm}$ and $665 \mathrm{~nm}$. The E4/E6 ratio was calculated to determine the degree of aromaticity.

\subsection{FTIR Analysis}

For the identification of structural and functional groups present in the extracted humic acid, FTIR analysis was conducted. Humic acid was mixed thoroughly with $200 \mathrm{mg}$ dried $\mathrm{KBr}$ and pellets were obtained. The pellets were then placed into FTIR Spectrum-65 (Perkin Elmer, Waltham, MA, USA) in $4000-500 \mathrm{~cm}^{-1}$ region for further investigation.

\subsection{CHNSO Elemental Analysis}

The elemental composition of humic acid was measured using CHNS Analyzer (LECO TruMac Series, Saint Joseph, MI, USA) according to ASTM standard. It was used to investigate the relative quantities of $\mathrm{C}, \mathrm{H}, \mathrm{N}, \mathrm{O}$, and $\mathrm{S}$. Data were analyzed on ash-free basis. Oxygen content was calculated using the formula:

$$
\mathrm{O}=100-(\mathrm{C}+\mathrm{H}+\mathrm{N}+\mathrm{S})
$$

\subsection{SEM Analysis}

Scanning electron microscopy model MIRA3 TESCAN (Japan), located at Institute of Space and Technology, Pakistan, fitted with energy dispersive X-ray analyzer and energy dispersive spectroscopy EDS was used to examine the elemental composition of produced humic acid from native lignite and bituminous coal. Deformation occurs morphologically after producing humic acid from $\mathrm{HNO}_{3}$ treatment of both types of coal.

\section{Results and Discussion}

\subsection{Gravimetric Determination of Humic Acid Using Different KOH Concentrations}

The $\mathrm{HNO}_{3}$ pretreated lignite and bituminous coal sample was treated with different percentages of $\mathrm{KOH}$, i.e., $0.5 \%, 1.5 \%, 2.5 \%, 3.5 \%$, and $4.5 \%$, for finding out the maximum yield of produced humic acid after alkali treatment. Figure 1 shows the effect of different concentrations of $\mathrm{KOH}$ on the percentage yield of extraction of humic acid from lignite and bituminous coal. The maximum yield was obtained using $4.5 \% \mathrm{KOH}$. About $31.7 \%$ of humic acid was extracted from bituminous coal and $42.6 \%$ from lignite coal by using a $4.5 \%$ concentration of $\mathrm{KOH}$, while $3.5 \%$ of used $\mathrm{KOH}$ concentration produces about $23.5 \%$ and $30.98 \%$ from bituminous and lignite coal, respectively. In one of the studies investigated by Zara et al. [23], the maximum yield of humic acid produced from lignite coal was obtained using a $3.5 \% \mathrm{KOH}$ concentration. In the present study, $0.5 \%, 1.5 \%$, and $2.5 \%$ concentration of $\mathrm{KOH}$ produce $7.54 \%, 11.38 \%$, and $17.98 \%$ yield of humic acid from bituminous coal, while $9.98 \%, 13.45 \%$, and $21.89 \%$ from lignite coal, respectively. This shows that the $0.5 \%$, $1.5 \%$, and $2.5 \%$ concentration of $\mathrm{KOH}$ did not produce the maximum content of humic acid 
for both types of coal. Zara et al. [23] also showed the $2.5 \%$ and $3 \% \mathrm{KOH}$ concentration does not produce the maximum yield of humic acid from lignite coal.

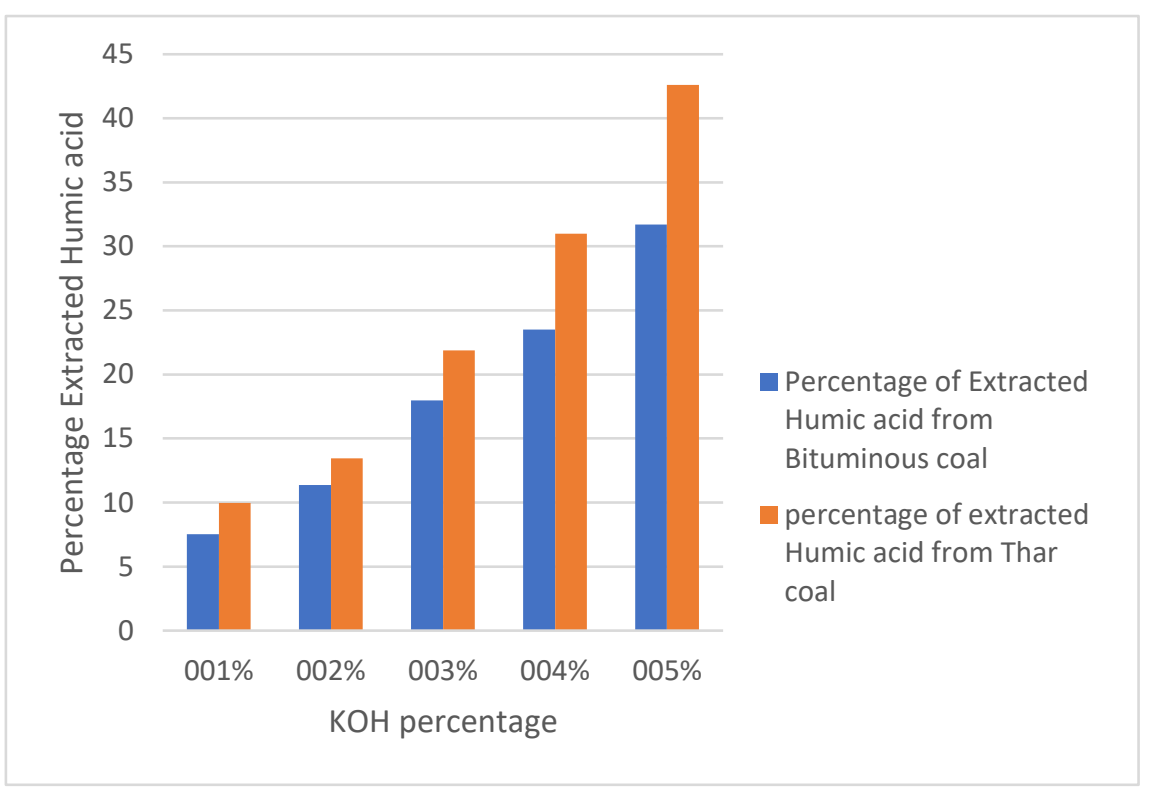

Figure 1. Gravimetric determination of humic acid extracted from lignite and bituminous coal using different $\mathrm{KOH}$ percentages.

\subsection{Humic Acid Yield Using $\mathrm{NaOH}$}

Table 1 shows the percentage yield of humic acid from both types of lignite and bituminous coal obtained by using alkali treatment $\mathrm{NaOH}$. The purity, quality, and properties of humic acid directly depend on the method and source of their extraction. This defines their application further in industry and agriculture fields. The added coal with sodium hydroxide results in the formation of sodium cations in a hydroxide state that can replace the protons into the humic acid molecules, resulting in their activation and dissolution. This alkali extraction process results in the conversion of insoluble humic acids to soluble salts, i.e., sodium humate [24]. The extraction using $\mathrm{NaOH}$ confirms the maximum yield of organic material [25]. In the present study, the humic acid yield from native lignite coal was $21.15 \%$ and bituminous coal was $11.6 \%$, while the $\mathrm{HNO}_{3}$ pretreatment showed about $57.8 \%$ humic acid yield from lignite coal and $46.9 \%$ from bituminous coal. Adnan et al. [26] reported a maximum yield of $54.2 \%$ from $\mathrm{HNO}_{3}$ pretreated sub-bituminous coal, while Zara et al. [23] showed a $24.6 \%$ humic acid yield from lignite coal. Ehsan Sarlaki et al. [3] reported about $95 \%$ humic acid yield from lignite coal using $\mathrm{NaOH}$ alkali extraction and membrane purification system.

Table 1. Percentage yield of derived humic acid from native and $\mathrm{HNO}_{3}$ treated coal.

\begin{tabular}{ccc}
\hline S.No & Types of Treated Coal & \% Yield of Humic Acid Using NaOH \\
\hline 1. & Native lignite coal & 21.15 \\
2. & Native bituminous coal & 11.6 \\
3. & $\mathrm{HNO}_{3}$ treated lignite coal & 57.8 \\
4. & $\mathrm{HNO}_{3}$ treated bituminous coal & 49.6 \\
\hline
\end{tabular}

Shakiba et al. [22] reported about $24 \%$ humic acid yield by alkali extraction. One of the research studies proposed by Muhammad et al. [8] showed the maximum yield of $50.80 \%$ by $\mathrm{HNO}_{3}$ treated bituminous coal, while the same researcher showed $60.60 \%$ yield of humic acid from lignite coal. It is seen that during the oxidation process the coal molecules gained an additional acidic group apart from degradation due to which they become soluble under alkali conditions. The degraded products mostly produced are 
a variety of aliphatics, hydroxybenzoic acids, benzene carboxylic acids humic acid, and humic substances. Shi kai et al. [17] obtained a high yield of humic acid by oxidizing coal with $\mathrm{NaOH}$. Haider et al. [7] investigated about $57 \%$ of humic acid yield from lignite coal using alkali $\mathrm{NaOH}$ treatment.

\subsection{UV-Vis Spectrophotometry of Produced Humic Acid}

In spectroscopic studies, the produced humic acid is most commonly investigated by the E4/E6 ratio of absorbance at $465 \mathrm{~nm}$ and $665 \mathrm{~nm}$. The E4/E6 is also called an index of humification that correlates the oxygen content of humic materials with the average molecular weight, and it decreases as the degree of condensation increases. This is a widely used ratio in humic substances study as a humification indicator (Table 2).

Table 2. E4/E6 ratio of produced humic acid by UV-Vis spectrophotometer.

\begin{tabular}{ccc}
\hline S.No & Types of Treated Coal & E4/E6 Ratio \\
\hline 1. & Native Thar lignite coal & 1.503 \\
2. & Native bituminous coal & 1.405 \\
3. & $\mathrm{HNO}_{3}$ treated Thar lignite coal & 1.879 \\
4. & $\mathrm{HNO}_{3}$ treated bituminous coal & 1.660 \\
\hline
\end{tabular}

In the present study as mentioned in Table 2, the native lignite coal has shown a greater E4/E6 ratio of 1.503 and bituminous coal of 1.405, while $\mathrm{HNO}_{3}$ treated lignite coal has shown a maximum E4/E6 ratio of 1.87 and bituminous coal of 1.6607. This means that native or raw lignite and bituminous coal had a high degree of aromaticity and molecular weight as their $\mathrm{E} 4 / \mathrm{E} 6$ ratio is lesser than $\mathrm{HNO}_{3}$ treated coal. The $\mathrm{HNO}_{3}$ treated coal had shown a higher E4/E6 ratio which indicated the decrease in molecular weight and aromatic content. This ultimately indicates increased bioactivity of the molecule. So, this shows that $\mathrm{HNO}_{3}$ treated humic acid had increased bioactivity as compared to native coal, which could be because of the pretreatment that resulted in the breakdown of aromatic rings and structures, and the introduction of some new functional groups into the acid molecule. The $\mathrm{HNO}_{3}$ attacks the carbon bonds present in the coal and those result in the deformation of the structure of coal by oxygenation, nitration, and other reactions. Adnan et al. [26] has shown higher E4/E6 in the raw coal than others, while Haider et al. [7] reported a lesser $\mathrm{E} 4 / \mathrm{E} 6$ ratio of native lignite coal.

\subsection{FTIR Analysis}

FTIR spectra of humic acid derived from native (raw) coal and $\mathrm{HNO}_{3}$ treated coal were obtained to determine the structural changes and presence of functional groups in the produced humic acid [27,28].

The spectrum shown in Figure 2 explains the humic acid produced from the native Thar lignite. The spectrum shows the peak at the range of $3300-3600 \mathrm{~cm}^{-1}$, which indicated the presence of $\mathrm{OH}$ groups and aliphatic primary amines. At $1630 \mathrm{~cm}^{-1} \mathrm{C}=\mathrm{C}$ stretching was investigated, and aromatic $\mathrm{C}-\mathrm{H}$ bending was detected at the range of $700-900 \mathrm{~cm}^{-1}$. At $1002 \mathrm{~cm}^{-1}$, the peak shows CO-O-CO stretching, which indicates the presence of an anhydride group. Figure 3 shows the IR spectra of humic acid produced from pretreated $\mathrm{HNO}_{3}$ Thar coal. This spectrum shows the peak at $3263.69 \mathrm{~cm}^{-1}$ that indicated the $\mathrm{OH}$ stretching and presence of some OH groups. At $2921.84 \mathrm{~cm}^{-1}$, an intensive peak of the carboxyl group was observed that showed strong hydrogen stretching and vibrations. At the range of $1000-1300 \mathrm{~cm}^{-1}$, the presence of esters, phenol, and stretching of $C=C$ and $\mathrm{C}=0$ groups were observed. Similarly, $\mathrm{C}=\mathrm{H}$ bending was observed in the range of $700-900 \mathrm{~cm}^{-1}$. 


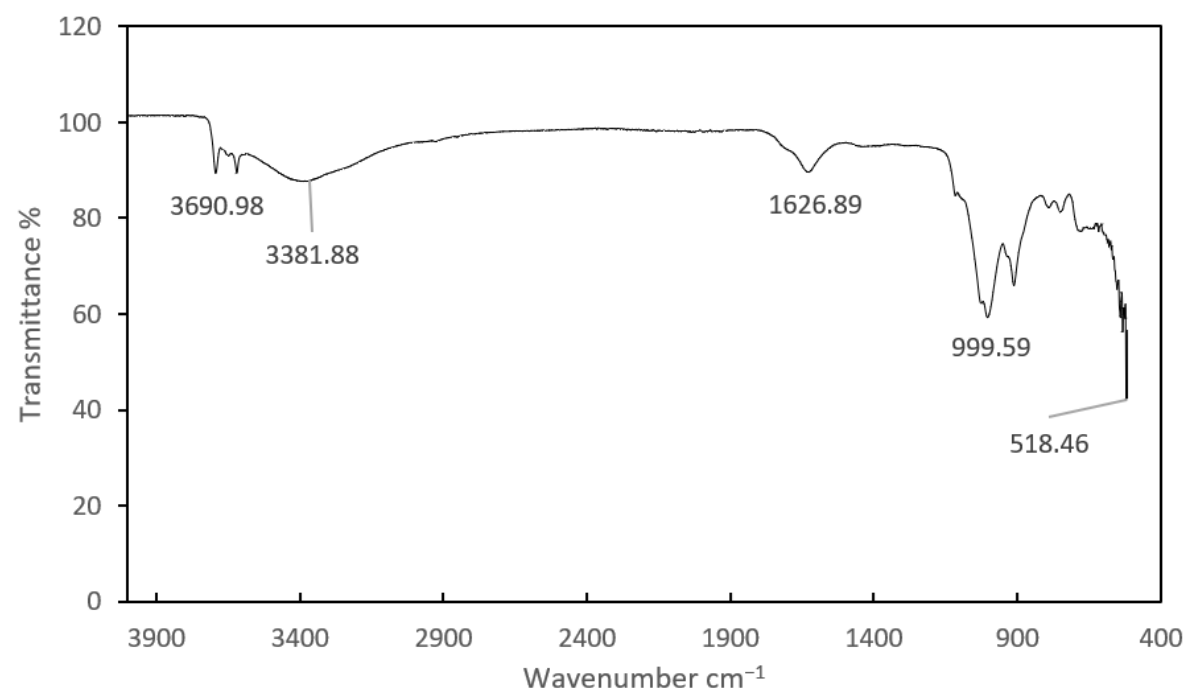

Figure 2. FTIR spectrum of humic acid derived from native lignite coal.

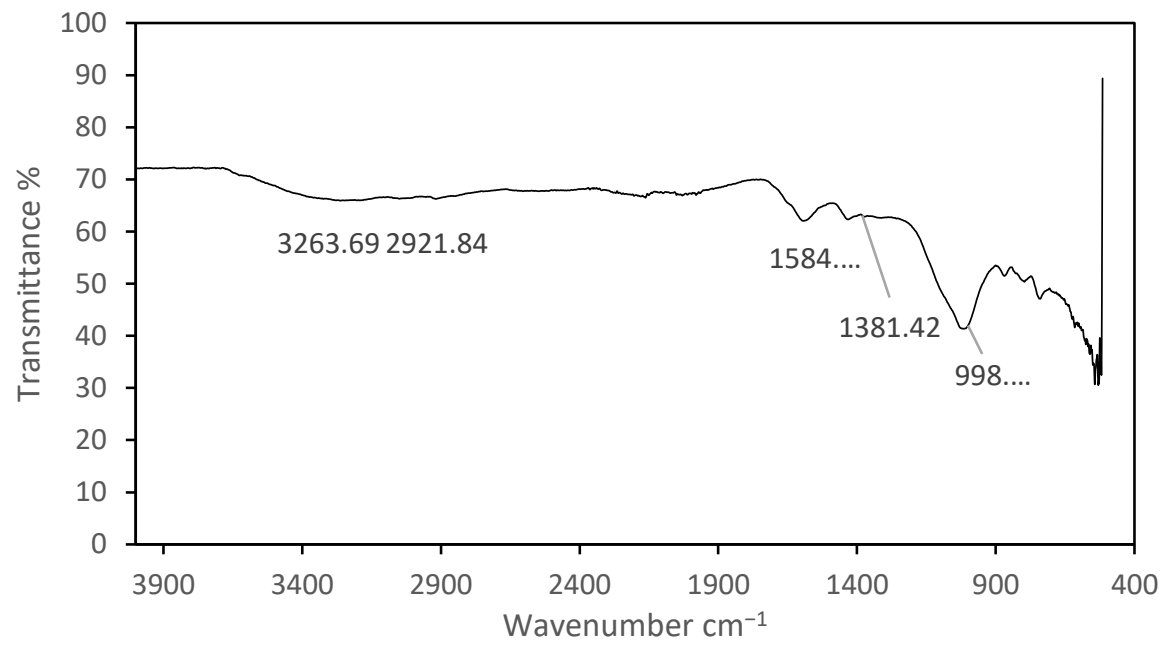

Figure 3. FTIR spectrum of humic acid derived from $\mathrm{HNO}_{3}$ treated lignite coal.

Figure 4 indicates the humic acid produced from Balochistan native or raw coal. The presence of peaks at the range of $3300-3700 \mathrm{~cm}^{-1}$ indicated the $\mathrm{OH}$ stretching and presence of $\mathrm{OH}$ groups. The peak at $1718.82 \mathrm{~cm}^{-1}$ shows $\mathrm{C}=\mathrm{C}$ stretching that indicated the presence of carboxylic groups, while the peak at $1618.82 \mathrm{~cm}^{-1}$ indicated the $\mathrm{C}=\mathrm{C}$ stretching presence of aromatic groups. C-H bending was investigated at the range of $700-900 \mathrm{~cm}^{-1}$, while mineral matter presence was also observed at the range of $400-500 \mathrm{~cm}^{-1}$ in $\mathrm{HNO}_{3}$ pretreated coal-derived humic acid.

Figure 5 indicates the IR spectrum of humic acid derived from $\mathrm{HNO}_{3}$ pretreated bituminous coal. This spectrum shows an immense number of peaks at different IR ranges. The peak at $3272.99 \mathrm{~cm}^{-1}$ indicated the presence of the $\mathrm{OH}$ group, while the peaks at the range of 2800-3000 $\mathrm{cm}^{-1}$ show the presence of asymmetric and symmetric stretching of aliphatic groups. At $2923.04 \mathrm{~N}-\mathrm{H}$, stretching was also indicated. Some aromatic group structures were observed at the range of $1500-1700 \mathrm{~cm}^{-1}$. Some phenolics, esters, and amine groups were revealed at $1533.08 \mathrm{~cm}^{-1}, 1355.01 \mathrm{~cm}^{-1}$, and $1233.48 \mathrm{~cm}^{-1}$. At the range of $900-1100 \mathrm{~cm}^{-1}$, weak $\mathrm{C}-\mathrm{O}$ stretching was observed while $\mathrm{C}-\mathrm{H}$ bending and the presence of mineral matter were observed at $400-700 \mathrm{~cm}^{-1}$. The $\mathrm{HNO}_{3}$ pretreatment oxidizes coal and breaks down certain aromatic rings and also loosens the structure of aromatic side chains. That is why the humic acid produced from $\mathrm{HNO}_{3}$ pretreated lignite and bituminous coal indicates the presence of more functional groups and shows various structural changes. 


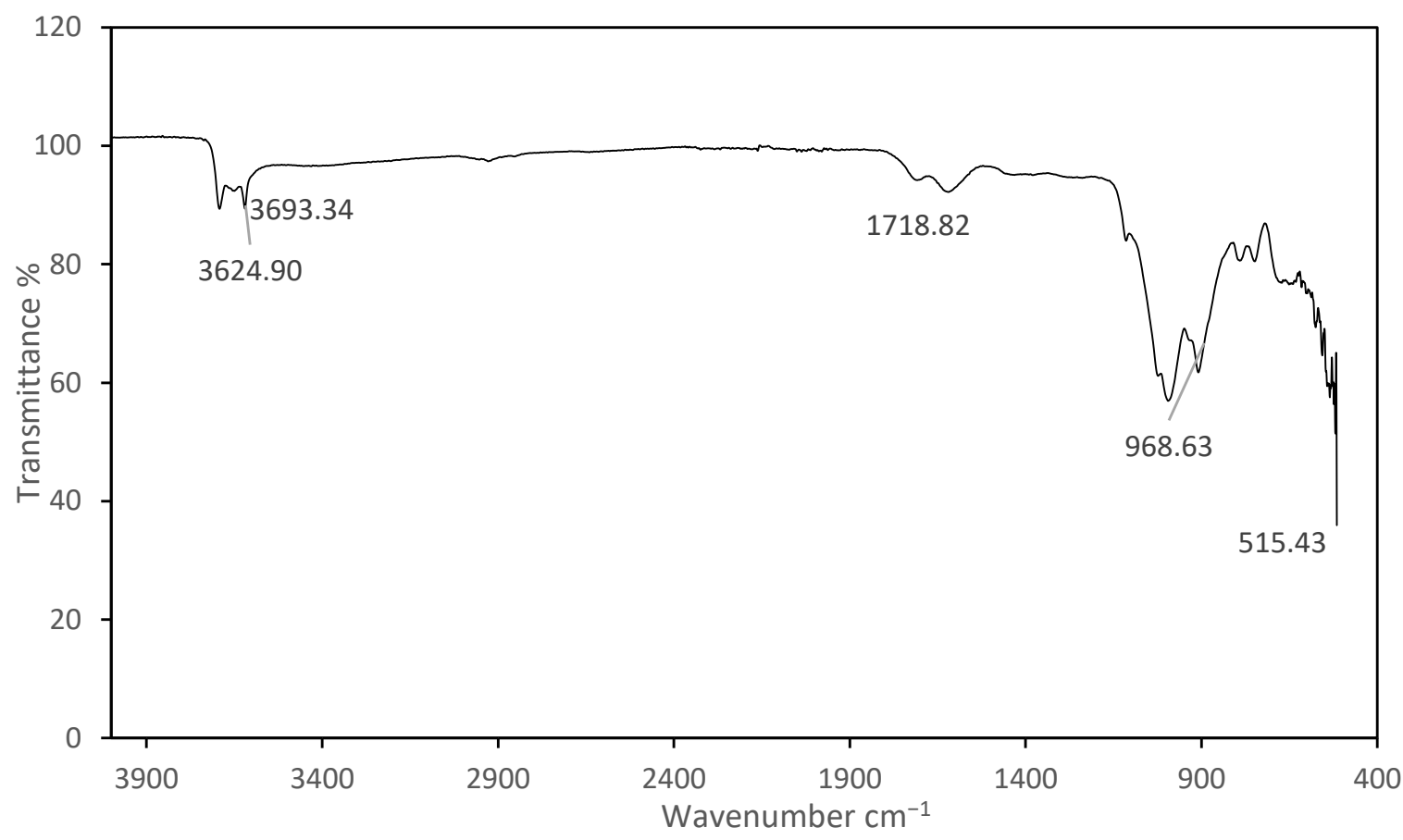

Figure 4. FTIR spectrum of humic acid derived from native bituminous coal.

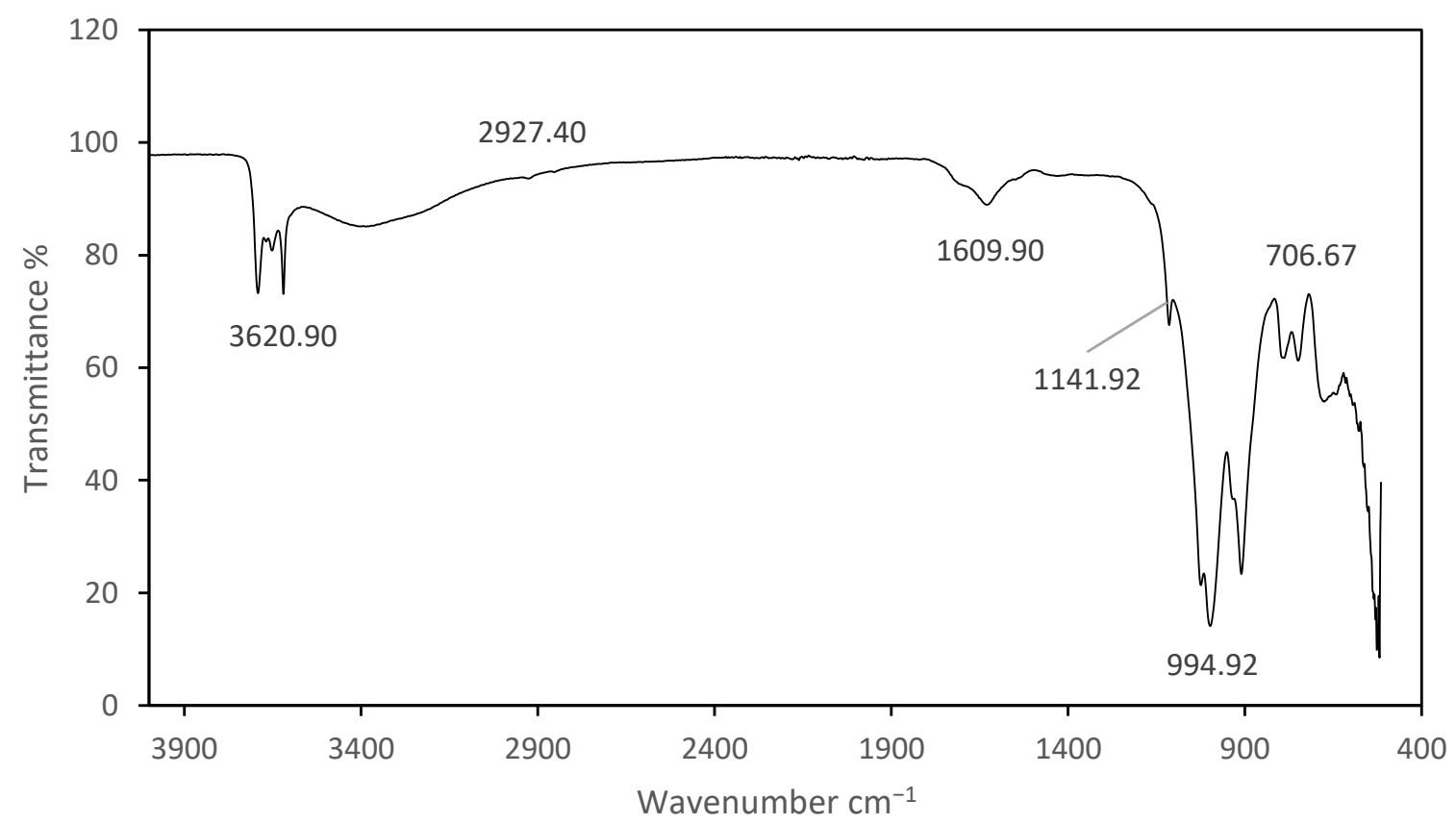

Figure 5. FTIR spectrum of humic acid produced from $\mathrm{HNO}_{3}$ treated bituminous coal.

Adnan et al. [26] reported very weak $\mathrm{C}-\mathrm{H}$ bending in raw sub-bituminous coal, while weak $\mathrm{C}$-O shoulder was observed in the case of $\mathrm{HNO}_{3}$ treated coal. Similarly, in the present study, very weak $\mathrm{C}-\mathrm{O}$ bending and stretching were observed in the case of humic acid derived from $\mathrm{HNO}_{3}$ treated bituminous coal. Adnan et al. [26] also showed the presence of carboxylic groups for $\mathrm{HNO}_{3}$ treated coal. Syahren et al. [29] also showed the clear peaks at $1700-1720 \mathrm{~cm}^{-1}$ that indicated $\mathrm{C}=\mathrm{O}$ stretch, $\mathrm{C}=\mathrm{C}$ aromatics at $1620-1630 \mathrm{~cm}^{-1}$, and $\mathrm{C}-\mathrm{H}$ and $\mathrm{C}=\mathrm{O}$ distinct bands at $1220-1250 \mathrm{~cm}^{-1}$. Similar bands were observed in the present study for humic acid derived from $\mathrm{HNO}_{3}$ pretreatment. Priyanka Shaha and Supriya Sarkar [9] indicated the absence of $\mathrm{OH}$ stretch at $3040 \mathrm{~cm}^{-1}$ and $\mathrm{C}=\mathrm{C}$ bond at $1410 \mathrm{~cm}^{-1}$ for lignite $\mathrm{HNO}_{3}$ treated coal. Manoj et al. [30] showed the presence of $\mathrm{OH}$ groups in 
the range of $3500-3100 \mathrm{~cm}^{-1}$. This study also showed some N-H stretching in the range of $3100-3500 \mathrm{~cm}^{-1}$, while in the present study, $\mathrm{N}-\mathrm{H}$ stretching peaks were observed at $2600-2700 \mathrm{~cm}^{-1}$ range.

\subsection{Elemental Analysis of Humic Acid}

The results of the elementary composition of humic acid derived from lignite and bituminous native coal and nitric acid-treated coal are listed in Table 3. The carbon content was reduced in the case of $\mathrm{HNO}_{3}$ treated coal, as compared to raw coal, in both lignite and bituminous types of coal. With the other coal contents, such as nitrogen and sulfur, there was a slight difference in the case of $\mathrm{HNO}_{3}$ treated lignite coal. The oxygen content increased in $\mathrm{HNO}_{3}$ treated lignite coal. This is because of the oxidation process by the use of nitric acid that resulted in the addition of more oxygen-containing functional groups.

Table 3. Elemental composition and percentage yield of Humic acid derived from Native and $\mathrm{HNO}_{3}$ treated coal.

\begin{tabular}{|c|c|c|c|c|c|c|c|c|}
\hline \multirow{2}{*}{ HA From } & \multicolumn{5}{|c|}{ Elemental Analysis } & \multicolumn{2}{|c|}{ Atomic Ratio } & \multirow[t]{2}{*}{ Yield (\%) } \\
\hline & $\mathrm{C}$ & $\mathbf{H}$ & $\mathbf{N}$ & $\mathrm{O}$ & S & $\mathrm{H} / \mathrm{C}$ & $\mathrm{O} / \mathrm{C}$ & \\
\hline Raw Lignite coal & 72.2 & 4.44 & 1.97 & 18.07 & 3.31 & 0.06 & 0.25 & 44.2 \\
\hline $\mathrm{HNO}_{3}$ treated lignite coal & 69.21 & 4.35 & 2.77 & 20.37 & 3.30 & 0.06 & 0.29 & 64.1 \\
\hline HA from native bituminous Coal & 56.20 & 10.99 & 3.07 & 18.59 & 11.15 & 0.19 & 0.18 & 38.8 \\
\hline $\mathrm{HA}$ from $\mathrm{HNO}_{3}$ treated bituminous coal & 53.2 & 9.89 & 5.37 & 21.38 & 10.07 & 0.185 & 0.40 & 58.4 \\
\hline
\end{tabular}

In the case of bituminous coal, the carbon content of humic acid derived from raw coal is more as compared to $\mathrm{HNO}_{3}$ treated coal. There was also a reduction in sulfur content which showed that desulphurization of coal occurs in the case of $\mathrm{HNO}_{3}$ derived humic acid and reduced carbon content showed decarbonization. The nitrogen content was also higher than raw coal and this is because, during oxidation, the nitration occurs which introduces nitrate as a functional group during $\mathrm{HNO}_{3}$ pretreatment of coal.

One of the studies reported by Patti et al. [31] also investigated the nitrogen into $\mathrm{HNO}_{3}$ oxidized brown coal and $\mathrm{NO}_{2}$ molecule added during the oxidation process. MacPhee et al. [32] used a technique, TG-FTIR, which reported that the oxidation by $\mathrm{HNO}_{3}$ produced oxygen-containing functional groups that were not reported in native coal. There was an increase in percentage in the case of nitrogen content which is because of the nitration taking place because of the phenomenon of the process of nitration. In [25], the same trend was also reported. Adnan et al. [26] investigated the higher content of carbon in the case of raw coal followed by $\mathrm{HNO}_{3}$ treated sub-bituminous coal. Dong et al. [33] also reported the same trends with lignite coal.

The $\mathrm{H} / \mathrm{C}$ atomic ratio was shown to be almost the same in the case of lignite coal, while bituminous coal showed a slight decrease in the $\mathrm{H} / \mathrm{C}$ ratio. The slight decrease in $\mathrm{H} / \mathrm{C}$ ratio in bituminous coal indicated higher aromatic condensation and high molecular mass fraction. Adnan et al. [26] reported a narrow range of $\mathrm{H} / \mathrm{C}$ ratio for sub-bituminous coal. There seemed a slight increase in the $\mathrm{O} / \mathrm{C}$ ratio of lignite and bituminous raw coal, as well as nitric acid-treated coal. This shows that some oxygen-containing fraction or content is present as an organic material, e.g., $\mathrm{COOH}$ group. The range of $\mathrm{O} / \mathrm{C}$ content is 0.33 to 0.40 . Adnan et al. [26] investigated 0.540 to $0.671 \mathrm{O} / \mathrm{C}$ content in sub-bituminous coal. Ehsan et al. [3] studied the lowest $\mathrm{O} / \mathrm{C}$ content in lignite-derived humic acid as compared to standard humic acid. XU-Yun-long et al. [34] investigated reduced carbon, hydrogen, sulfur, and increased nitrogen and oxygen content. The coal oxidation resulted in a chemical reaction between nitric acid and functional groups present in coal, i.e., oxidation of side chains that produce esters, aldehydes, and ketones, and nitration and aromatic ring carboxylation also occurred.

One of the methods proposed by Kashif et al. [35] extracted humic acid from Bulgarian lignite coal by using $\mathrm{NaOH}$ and $\mathrm{HCl}$ for precipitation of humic acid and obtained about $83 \%$ yield of humic acid content. Another method proposed by Hofrichter et al, [25] explained 
the mixing of south Moravian lignite coal with base $\mathrm{NaOH}(0.5 \mathrm{~mol} / \mathrm{L})$ and $\mathrm{Na}_{4} \mathrm{P}_{2} \mathrm{O}_{7}$ $(0.1 \mathrm{~mol} / \mathrm{L})$ followed by $\mathrm{HCl}-\mathrm{HF}$ solution $(0.5 \%)$ and humic acid, were finally precipitated by addition of $\mathrm{H}_{2} \mathrm{O}_{2}$ and $\mathrm{HNO}_{3}$ treatment.

\subsection{SEM Analysis}

For characterizing the produced humic acid morphologically from raw coal, as well as $\mathrm{HNO}_{3}$ treated lignite and bituminous coal, scanning electron microscopy was performed. The elemental distribution on the surface of each sample was also obtained by EDS, as shown in Figure 6. Figure 6a shows the SEM image of humic acid produced from raw lignite coal and the major elements observed in Figure $7 \mathrm{a}$ are $\mathrm{C}, \mathrm{O}, \mathrm{Si}$, and $\mathrm{Al}$, with some other minor elements such as $\mathrm{S}, \mathrm{Cl}, \mathrm{Ca}, \mathrm{Ti}$, and Fe. After treating lignite raw coal with $\mathrm{HNO}_{3}$, shown in Figure $6 \mathrm{~b}$, the produced humic acid had shown some structural and morphological changes along with some visible differences in elemental composition. The elemental composition, as shown in Figure $7 \mathrm{~b}$, of $\mathrm{HNO}_{3}$ treated lignite coal showed the incorporation of nitrogen and oxygen as major elements, which indicated the formation of $-\mathrm{NO}_{2}$ group and some other new compounds. The porous structure on the surface indicates the deformation of some aliphatic and aromatic bonds present in the structure of coal. Some minor elements that were also observed include $\mathrm{Al}, \mathrm{Ca}$, and sulphur, which were reduced and dislodged, while chlorine, phosphorus, and potassium were also indicated, the formation of some new elements produced as a result of acidic treatment of coal with $\mathrm{HNO}_{3}$.

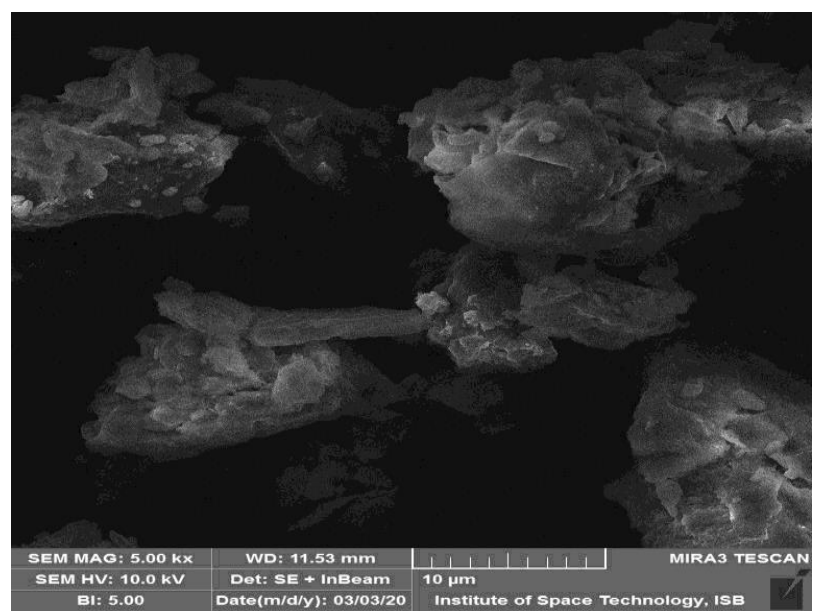

(a)

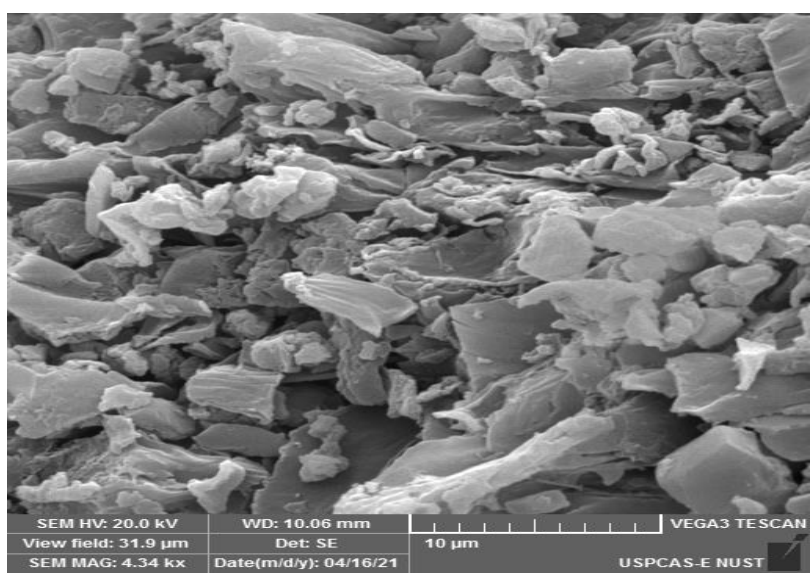

(c)

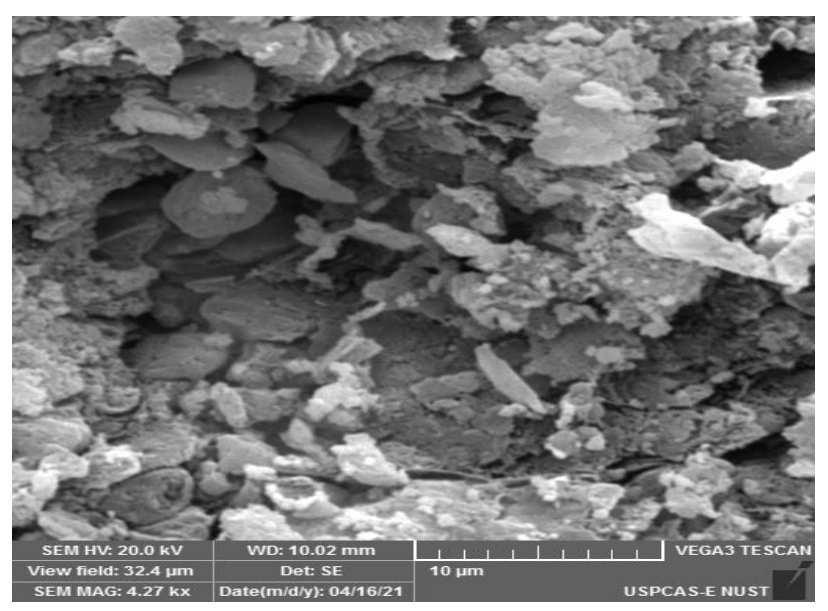

(b)

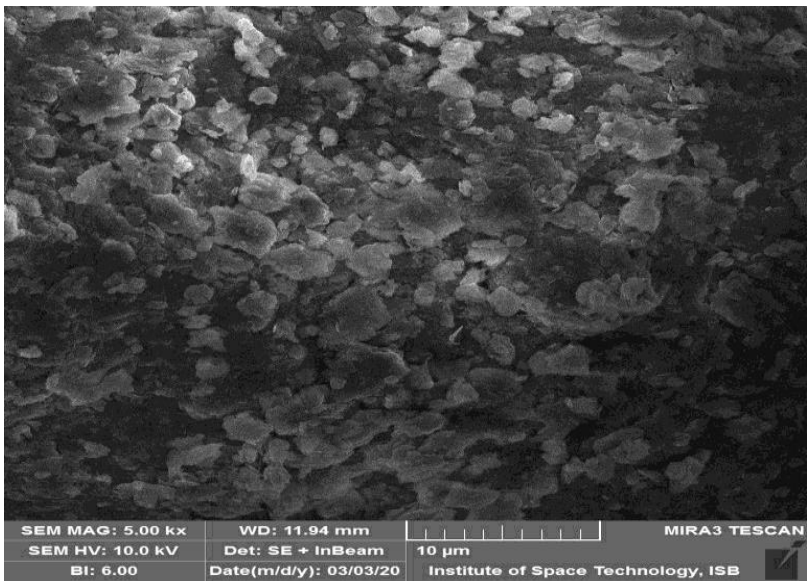

(d)

Figure 6. (a) Humic acid from raw lignite coal, (b) Humic acid from $\mathrm{HNO}_{3}$ treated lignite Coal, (c) Humic acid from raw Bituminous Coal, (d) Humic acid from $\mathrm{HNO}_{3}$ treated bituminous coal. 


\begin{tabular}{l|ll}
\hline Element & Weight $\%$ & Atomic\% \\
& & \\
C K & 20.95 & 30.11 \\
O K & 47.61 & 51.38 \\
Na K & 2.02 & 1.52 \\
Al K & 8.91 & 5.70 \\
Si K & 13.53 & 8.31 \\
S K & 0.63 & 0.34 \\
Cl K & 3.40 & 1.65 \\
Ca K & 0.40 & 0.17 \\
Ti K & 0.54 & 0.19 \\
Fe K & 2.02 & 0.62 \\
\hline
\end{tabular}

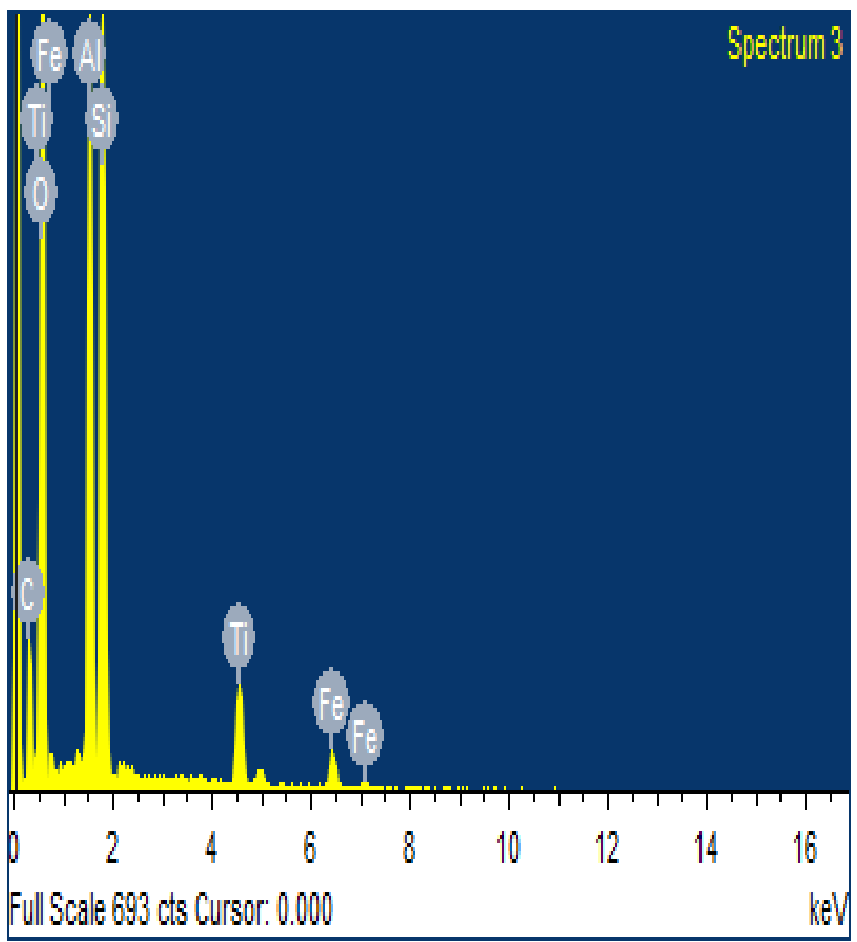

(a)

\begin{tabular}{l|ll}
\hline Element & Weight\% & Atomic\% \\
C K & 45.67 & 52.68 \\
N K & 21.00 & 20.77 \\
O K & 27.58 & 23.88 \\
Na K & 1.49 & 0.90 \\
Mg K & 0.34 & 0.19 \\
Al K & 0.34 & 0.17 \\
P K & 1.16 & 0.52 \\
S K & 0.54 & 0.23 \\
Cl K & 0.46 & 0.18 \\
K K & 0.86 & 0.31 \\
Ca K & 0.31 & 0.11 \\
Fe K & 0.25 & 0.06 \\
& & \\
Totals & 100.00 & \\
\hline
\end{tabular}

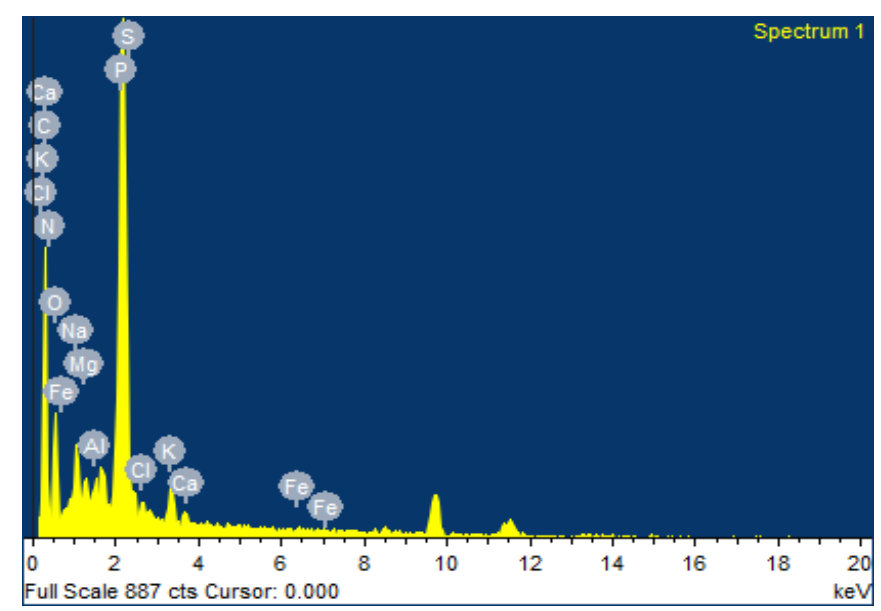

(b)

Figure 7. Cont. 


\begin{tabular}{l|ll}
\hline Element & Weight\% & Atomic\% \\
& & \\
C K & 12.98 & 18.75 \\
O K & 61.37 & 66.56 \\
Al K & 9.04 & 5.81 \\
Si K & 11.59 & 7.16 \\
Ti K & 3.18 & 1.15 \\
Fe K & 1.85 & 0.57 \\
& & \\
\hline
\end{tabular}

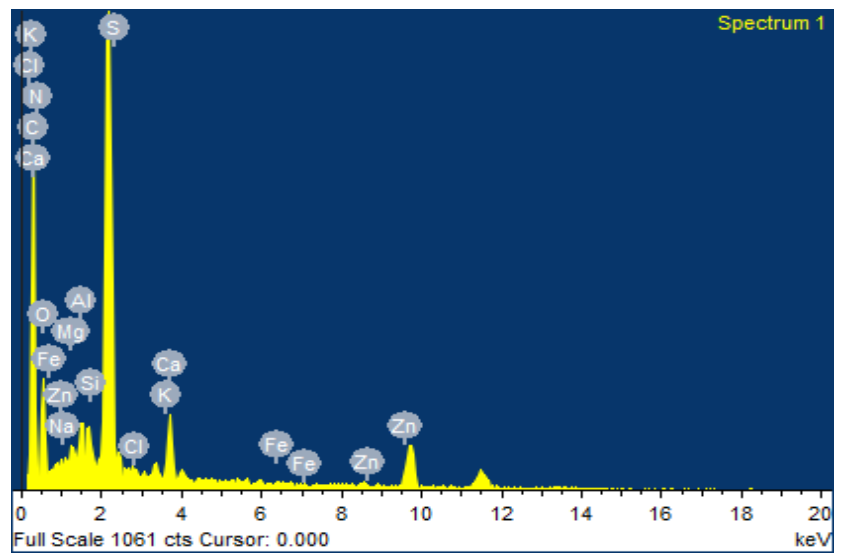

(c)

\begin{tabular}{l|ll}
\hline Element & Weight\% & Atomic\% \\
C K & 48.66 & 56.21 \\
N K & 17.31 & 17.14 \\
O K & 28.05 & 24.33 \\
Na K & 0.10 & 0.06 \\
Mg K & 0.42 & 0.24 \\
Al K & 0.98 & 0.51 \\
Si K & 0.10 & 0.05 \\
S K & 0.31 & 0.14 \\
Cl K & 0.20 & 0.08 \\
K K & 0.45 & 0.16 \\
Ca K & 2.70 & 0.94 \\
Fe K & 0.20 & 0.05 \\
Zn K & 0.51 & 0.11 \\
Totals & 100.00 & \\
\hline & & \\
\hline
\end{tabular}

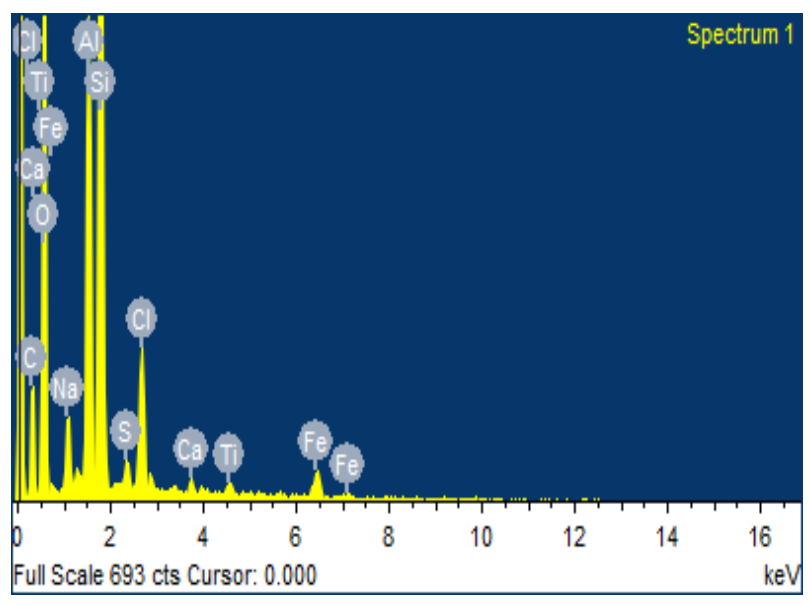

(d)

Figure 7. (a) Humic acid from raw lignite coal, (b) Humic acid from $\mathrm{HNO}_{3}$ treated lignite coal, (c) Humic acid from raw bituminous coal, (d) Humic acid from $\mathrm{HNO}_{3}$ treated bituminous coal. 
Similarly, Figure $6 \mathrm{c}, \mathrm{d}$ indicates the humic acid produced from raw bituminous coal and $\mathrm{HNO}_{3}$ treated bituminous coal. The elemental composition, as shown in Figure 7c, indicated the presence of major elements such as carbon, oxygen, and silicon. The presence of nitrogen in treated bituminous coal with $\mathrm{HNO}_{3}$ indicated the incorporation of nitrogencontaining compounds such as $-\mathrm{NO}_{2}$. This showed that treatment of bituminous coal with nitric acid results in the breakdown of the toughest aromatic bonds and aliphatic side chains present in the structure of coal. That is why the produced humic acid also indicated the presence of nitrogen on the surface by elemental analysis, shown in Figure 7d. Some other elements also seemed to be present, such as $\mathrm{Na}, \mathrm{Mg}, \mathrm{S}, \mathrm{Ca}, \mathrm{K}$, and chlorine. The acidic pretreatment destroyed the hydrogen bonds and Van der Waals forces as well as $\pi-\pi$ bonds proposed by Piccolo [14] and coworkers. One of the studies conducted by Chu-fang et al. [34] reported the introduction of chlorine and dislodging of $\mathrm{Al}$ and $\mathrm{Ca}$ ions by treating coal with acid and producing humic acid from it. Some of the crystal or needle-like structures were also shown on humic acid produced from $\mathrm{HNO}_{3}$ treated bituminous coal, which clearly indicated that some new structures have been produced. Another study conducted by Stefane et al. [16] had shown the SEM images of produced humic acid from lignite coal at different magnifications. They also reported the presence of weak Van der Waals forces, hydrogen bonds, and the presence of porous structure on the surface of humic acid.

\section{Conclusions}

In the present study, two different types of coal, i.e., low rank and high rank coal, were used for extracting humic acid using different concentrations, i.e., $0.5 \%, 1.5 \%, 2.5 \%$, $3.5 \%$, and $4.5 \%$, of $\mathrm{KOH}$ solutions and $0.1 \mathrm{M} \mathrm{NaOH}$ was used as an alkaline treatment for the production of organic matter (humic acid). The particle size of coal taken was 60 mesh $(0.25 \mathrm{~mm})$ and the samples were allowed for agitation or continuous shaking for $24 \mathrm{~h}$. The extracted humic acid was separated from the supernatant by centrifugation, dried at $60{ }^{\circ} \mathrm{C}$, and analyzed using the gravimetric method, UV-Visible spectroscopy, FTIR, and SEM-EDS. According to the analysis, $4.5 \%$ concentration of $\mathrm{KOH}$ had shown maximum yield of humic acid in both types of coal. The percentage of humic acid using $\mathrm{NaOH}$ for native lignite and bituminous coal was $21.15 \%$ and $11.6 \%$, and for $\mathrm{HNO}_{3}$ treated coal, the percentage for lignite and bituminous coal was $57.8 \%$ and $46.9 \%$, respectively. FTIR results of $\mathrm{HNO}_{3}$ treated coal clearly indicated the presence of $\mathrm{N}-\mathrm{H}$ group peak at $2923.04 \mathrm{~cm}^{-1}$ in case of bituminous coal and introduction of the nitro group in lignite coal at $2921.84 \mathrm{~cm}^{-1}$, while both peaks were absent in native coal FTIR spectrum. The elemental analysis of $\mathrm{HNO}_{3}$ treated coal had shown the reduction in carbon content and a slight change in sulphur and nitrogen and an increase in oxygen content that confirmed the oxidation process had occurred. The $\mathrm{O} / \mathrm{C}$ ratio also increased in the case of $\mathrm{HNO}_{3}$ treated coal. The SEM-EDS analysis had shown clear morphological and structural changes in the produced humic acids by $\mathrm{HNO}_{3}$ treatment as well as native coal. The EDS analysis had also shown clear changes in the elemental composition of lignite and bituminous coal after treatment. The porous structure in SEM images clearly indicated some breakdown of aliphatic and aromatic side chains by treating with $\mathrm{HNO}_{3}$. On the basis of this study, it can be suggested that both lignite and bituminous coal can be used as a raw feed to produce and extract humic acid at a commercial scale.

Author Contributions: Conceptualization, N.F. and A.J.; methodology, Z.H.; software, R.L.; validation, B.A., R.H. and T.A.; formal analysis, T.S.; investigation, Z.A.A.; resources, M.O.; data curation, S.A.; writing —original draft preparation, N.F.; writing-review and editing, M.I.A.; visualization, N.A.; supervision, M.I.A.; project administration, M.S.; funding acquisition, M.S. All authors have read and agreed to the published version of the manuscript.

Funding: Authors are grateful to the Researchers Supporting Project No.(RSP-2021/1), King Saud University, Riyadh, Saudi Arabia.

Institutional Review Board Statement: Not applicable. 
Informed Consent Statement: Not applicable.

Data Availability Statement: Not applicable.

Conflicts of Interest: The authors declare no conflict of interest.

\section{References}

1. Nasir, S.; Sarfaraz, T.B.; Verheyen, T.V.; Chaffee, A.L. Structural elucidation of humic acids extracted from Pakistani lignite using spectroscopic and thermal degradative techniques. Fuel Process. Technol. 2011, 92, 983-991. [CrossRef]

2. Haider, R.; Ghauri, M.A.; SanFilipo, J.R.; Jones, E.J.; Orem, W.H.; Tatu, C.A.; Akhtar, K.; Akhtar, N. Fungal degradation of coal as a pretreatment for methane production. Fuel 2013, 104, 717-725. [CrossRef]

3. Sarlaki, E.; Paghaleh, A.S.; Kianmehr, M.H.; Vakilian, K.A. Extraction and purification of humic acids from lignite wastes using alkaline treatment and membrane ultrafiltration. J. Clean. Prod. 2019, 235, 712-723. [CrossRef]

4. Bibi, S.; Ahmad, A.; Anjum, M.A.R.; Haleem, A.; Siddiq, M.; Shah, S.S.; Al Kahtani, A. Photocatalytic degradation of malachite green and methylene blue over reduced graphene oxide (rGO) based metal oxides (rGO-Fe3O4/TiO2) nanocomposite under UV-visible light irradiation. J. Environ. Chem. Eng. 2021, 9, 105580. [CrossRef]

5. Chen, X.; Xu, Y.; Fan, M.; Chen, Y.; Shen, S. The stimulatory effect of humic acid on the co-metabolic biodegradation of tetrabromobisphenol A in bioelectrochemical system. J. Environ. Manag. 2019, 235, 350-356. [CrossRef]

6. Mustafa, A.; Ahmad, T.; Akhtar, J.; Shahzad, K.; Sheikh, N.; Munir, S. Agglomeration of Makarwal coal using soybean oil as agglomerant. Energy 2016, 38, 733-3739. [CrossRef]

7. Haider, R.; Ghauri, M.A.; Akhtar, K. Isolation of coal degrading fungus from drilled core coal sample and effect of prior fungal pretreatment on chemical attributes of extracted humic acid. Geomicrobiol. J. 2015, 32, 944-953. [CrossRef]

8. Asif, M. Comparative Study on Extraction of Humic Acid from Pakistani Coal Samples by Oxidizing the Samples with Hydrogen Peroxide. ASEAN J. Sci. Eng. 2021, 2, 1-8.

9. Saha, P.; Sarkar, S. Microbial degradation of coal into a value added product. Int J. Coal Prep. Utiliz. 2019, 39, 1-19. [CrossRef]

10. Fong, S.S.; Seng, L.; Majri, N.B.; Mat, H.B. A comparative evaluation on the oxidative approaches for extraction of humic acids from low rank coal of Mukah, Sarawak. J. Braz. Chem. Soc. 2007, 18, 34-40. [CrossRef]

11. Aravind, M.; Ahmad, A.; Ahmad, I.; Amalanathan, M.; Naseem, K.; Mary, S.M.; Parvathiraja, C.; Hussain, S.; Algarni, T.S.; Pervaiz, M.; et al. Critical green routing synthesis of silver NPs using jasmine flower extract for biological activities and photocatalytical degradation of methylene blue. J. Environ. Chem. Eng. 2021, 9, 104877. [CrossRef]

12. Ahmad, A.; Jini, D.; Aravind, M.; Parvathiraja, C.; Ali, R.; Kiyani, M.Z.; Alothman, A. A novel study on synthesis of egg shell based activated carbon for degradation of methylene blue via photocatalysis. Arab. J. Chem. 2020, 13, 8717-8722. [CrossRef]

13. Malik, A.Y.; Ali, M.I.; Jamal, A.; Farooq, U.; Khatoon, N.; Orem, W.H.; Barnhart, E.P.; SanFilipo, J.R.; He, H.; Huang, Z. Coal biomethanation potential of various ranks from Pakistan: A possible alternative energy source. J. Clean. Prod. 2020, 255, 120-177. [CrossRef]

14. Piccolo, A.; Conte, P.; Cozzolino, A. Effects of mineral and monocarboxylic acids on the molecular association of dissolved humic substances. Eur. J. Soil Sci. 1999, 50, 687-694. [CrossRef]

15. Cheng, G.; Niu, Z.; Zhang, C.; Zhang, X.; Li, X. Extraction of humic acid from lignite by KOH-hydrothermal method. Appl. Sci. 2019, 9, 1356. [CrossRef]

16. Barhoumi, A.; Ncib, S.; Chibani, A.; Brahmi, K.; Bouguerra, W.; Elaloui, E. High-rate humic acid removal from cellulose and paper industry wastewater by combining electrocoagulation process with adsorption onto granular activated carbon. Ind. Crop. Prod. 2019, 140, 111715. [CrossRef]

17. Shi, K.; Tao, X.; Hong, F.; He, H.; Ji, Y.; Li, J. Mechanism of oxidation of low rank coal by nitric acid. J. Coal Sci. Eng. 2012, 18, 396-399. [CrossRef]

18. Ahmad, A.; Mubharak, N.M.; Naseem, K.; Tabassum, H.; Rizwan, M.; Najda, A.; Kashif, M.; Bin-Jumah, M.; Hussain, A.; Shaheen, A.; et al. Recent advancement and development of chitin and chitosan-based nanocomposite for drug delivery: Critical approach to clinical research. Arab. J. Chem. 2020, 13, 8935-8964. [CrossRef]

19. Skhonde, M.P.; Herod, A.A.; Van der Walt, T.J.; Tsatsi, W.L.; Mokoena, K. The effect of thermal treatment on the compositional structure of humic acids extracted from South African bituminous coal. Int. J. Miner. Process. 2006, 81, 51-57. [CrossRef]

20. Burange, A.S.; Ahmad, A.; Luque, R. Electrophilicity in heterogeneous catalysis: Role of surface and sub-surface modification. Catal. Sci. Technol. 2021. [CrossRef]

21. Xavier, D.; Silva, A.S.; Santos, R.P.; Mesko, M.; Costa, S.; Freire, V.; Cavada, B.; Martins, J. Characterization of the coal humic acids from the Candiota coalfield, Brazil. Int. J. Agric. Sci. 2012, 4, 238-242.

22. Shakiba, N. Investigation of the Effective Parameters on Separation and Purification of Humic Acid from the Leonardite Humate Using a Proper Filter. Master's Thesis, University of Tehran, Tehran, Iran, 2016.

23. Zara, M.; Ahmad, Z.; Akhtar, J.; Shahzad, K.; Sheikh, N.; Munir, S. Extraction and characterization of humic acid from Pakistani lignite coals. Energy Sources Part A Recovery Util. Environ. Effects 2017, 39, 1159-1166. [CrossRef]

24. Saleem, M.; Irfan, M.; Tabassum, S.; Albaqami, M.D.; Javed, M.S.; Hussain, S.; Pervaiz, M.; Ahmad, I.; Ahmad, A.; Zuber, M. Experimental and theoretical study of highly porous lignocellulose assisted metal oxide photoelectrodes for dye-sensitized solar cells. Arab. J. Chem. 2021, 14, 102937. [CrossRef] 
25. Hofrichter, M.; Fritsche, W. Depolymerization of low-rank coal by extracellular fungal enzyme systems. II. The ligninolytic enzymes of the coal-humic-acid-depolymerizing fungus Nematoloma frowardii b19. Appl. Microbiol. Biotechnol. 1997, 47, 419-424. [CrossRef]

26. Sabar, M.A.; Ali, M.I.; Fatima, N.; Malik, A.Y.; Jamal, A.; Liaquat, R.; He, H.; Liu, F.-J.; Guo, H.; Urynowicz, M.; et al. Evaluation of humic acids produced from Pakistani subbituminous coal by chemical and fungal treatments. Fuel 2020, 278, 118301. [CrossRef]

27. Boral, P.; Varma, A.K.; Maity, S. Nitration of jharia basin coals, india: A study of structural modifications by XRD and FTIR techniques. Int. J. Coal Sci. Technol. 2021, 1-12.

28. Das, T.; Bora, M.; Tamuly, J.; Benoy, S.M.; Baruah, B.P.; Saikia, P.; Saikia, B.K. Coal-derived humic acid for application in acid mine drainage (AMD) water treatment and electrochemical devices. Int. J. Coal Sci. Technol. 2021, 1-12.

29. Syahren, A.M.; Wong, N.C. Extraction and chemical characteristics of nitro-humic acids from coals and composts. J. Trop Agric. Fd. Sc. 2008, 36, 269-279.

30. Manoj, B.; Narayanan, P. Study of changes to the organic functional groups of a high volatile bituminous coal during organic acid treatment process by FTIR spectroscopy. J. Miner. Mater. Characterisation Eng. 2013, 1, 39-43. [CrossRef]

31. Patti, A.F.; Verheyen, T.V.; Douglas, L.; Wang, X. Nitrohumic acids from Victorian brown coal. Sci. Tot. Environ. 1992, 113, 49-65. [CrossRef]

32. Macphee, J.M.; Giroux, T.P.; Charland, J.F.; Price, J.T. Detection of natural oxidation of coking coal by TG- FTIR mechanistic implications. Fuel 2004, 83, 1855-1860. [CrossRef]

33. Dong, L.H.; Yuan, Q.; Yuan, H. Changes of chemical properties of humic acids from crude and fungal transformed lignite. Fuel 2006, 85, 2402-2407. [CrossRef]

34. Wang, C.F.; Fan, X.; Zhang, F.; Wang, S.Z.; Zhao, Y.P.; Zhao, X.Y.; Zhao, W.; Zhu, T.G.; Lu, J.L.; Wei, X.Y. Characterization of humic acids extracted from a lignite and interpretation for the mass spectra. RSC Adv. 2017, 7, 20677-20684. [CrossRef]

35. Kashif, M.; Jaafar, E.; Bhadja, P.; Low, F.W.; Sahari, S.K.; Hussain, S.; Loong, F.K.; Ahmad, A.; AlGarni, T.S.; Shafa, M.; et al. Effect of potassium permanganate on morphological, structural and electro-optical properties of graphene oxide thin films. Arab. J. Chem. 2021, 14, 102953. [CrossRef] 